\title{
Virus adsorption process determines virus susceptibility in Heterosigma akashiwo (Raphidophyceae)
}

\author{
Kenji Tarutani, Keizo Nagasaki*, Mineo Yamaguchi \\ National Research Institute of Fisheries and Environment of Inland Sea, Maruishi 2-17-5, Hatsukaichi, \\ Hiroshima 739-0452, Japan
}

\begin{abstract}
We compared the adsorption kinetics of Heterosigma akashiwo virus clones 01 (HaV01) and 53 (HaV53) to several other $H$. akashiwo strains with differing viral susceptibility spectra. When a $\mathrm{HaV}$ strain was inoculated into its suitable host strain, only infectious virus particles (3 to $4 \%$ of direct count estimates) adsorbed to the host cells, and the adsorption coefficient was estimated to be 4.02 to $5.44 \times 10^{-8} \mathrm{ml} \mathrm{m^{-1 }}$; in contrast, virus adsorption to an unsuitable host strain was not detected. This suggests that virus adsorption is an important first step in determining the sensitivity or resistance of $H$. akashiwo strains to viral infection, and that it determines the strain-specific host specificity of $\mathrm{HaV}$.
\end{abstract}

KEY WORDS: Algal virus $\cdot$ Heterosigma akashiwo $\cdot$ Host range $\cdot$ Intraspecies host specificity $\cdot$ Viral adsorption Resale or republication not permitted without written consent of the publisher

\section{INTRODUCTION}

Heterosigma akashiwo virus (HaV) is a large $(\sim 0.2 \mu \mathrm{m})$, double-stranded DNA (dsDNA) virus infecting the harmful bloom-forming flagellate Heterosigma akashiwo (Hada) Hada (Nagasaki \& Yamaguchi 1997, Nagasaki et al. 1999a). Although H. akashiwo is a single species belonging to the genus Heterosigma (Throndsen 1996), its susceptibility to $\mathrm{HaV}$ is diverse among clonal strains (Nagasaki \& Yamaguchi 1998a, Nagasaki et al. 1999b, Tarutani et al. 2000, Tomaru et al. 2004b). Based on field surveys and cross-reactivity tests between the host clones and HaV clones, Tarutani et al. (2000) and Tomaru et al. (2004b) suggested that this strain-dependent infection may play an important role in determining the clonal composition and maintaining the intraspecies diversity of natural H. akashiwo populations.

Strain-specific host ranges have been found for other viruses infecting eukaryotic microalgae: Chlorella virus (CV; Reisser et al. 1988), Micromonas pusilla virus (MpV; Cottrell \& Suttle 1991, Sahlsten 1998), Heterosigma akashiwo nuclear inclusion virus (HaNIV; Lawrence et al. 2001), Heterocapsa circularisquama virus (HcV; Nagasaki et al. 2003), $H$. circularisquama RNA virus (HcRNAV; Tomaru et al. 2004a), and Rhizosolenia setigera RNA virus (RsRNAV; Nagasaki et al. 2004). However, few studies have determined the mechanisms of intraspecies host specificity. Onimatsu et al. (2004) identified a surface protein from a large dsDNA virus (CV) that interacts with the host cell wall. Nagasaki et al. (2005a) reported that the intraspecies host specificity of a dinoflagellate-infecting single-stranded RNA virus (HcRNAV) may be determined by the nano-structures on the virus surface, which influence the binding to suitable $H$. circularisquama clones.

In the present study we compare the kinetics of viral adsorption to several Heterosigma akashiwo strains with different viral susceptibility spectra. Our principal aim is to verify the strain-specific host range of $\mathrm{HaV}$ during the viral adsorption process. 


\section{MATERIALS AND METHODS}

We used $2 \mathrm{HaV}$ clones and 4 Heterosigma akashiwo strains. HaV01 was isolated from Unoshima Fishing Port (Fukuoka Prefecture, Japan), and HaV53 was isolated from Itsukaichi Fishing Port (northern Hiroshima Bay, Japan). Axenic strains of $H$. akashiwo (strains H93616, H94608, H98518-4 and H98527-6) were isolated from Itsukaichi Fishing Port. These were selected because they display differing viral susceptibilities to HaV01 and HaV53 (Table 1; Nagasaki \& Yamaguchi 1998a, Tarutani et al. 2000, K. Tarutani et al. unpubl. data). Algal cultures were grown in modified SWM3 medium enriched with $2 \mathrm{nM} \mathrm{Na}_{2} \mathrm{SeO}_{3}$ (Chen et al. 1969, Itoh \& Imai 1987, Imai et al. 1996), and incubated at $20^{\circ} \mathrm{C}$ using a $12: 12 \mathrm{~h}$ light:dark cycle (light provided by cool white fluorescent illumination FL40S D EDL D65, Toshiba, at $\sim 50 \mu \mathrm{mol}$ photons $\mathrm{m}^{-2} \mathrm{~s}^{-1}$ ).

Aliquots of $\mathrm{HaV}$ were inoculated into $25 \mathrm{ml}$ exponentially growing cultures of Heterosigma akashiwo at a multiplicity of infection of $\sim 0.1$. This corresponds to a total virus to host ratio of $\sim 3$, because 3 to $4 \%$ of the $\mathrm{HaV}$ particles stainable with DAPI (4'-6-diamidino-2phenylindole) were considered to be infectious (see 'Results and discussion'). As a control, an algal culture without viral inoculation was passed through a glass fiber filter (Whatman GF/F) and the same volume as the $\mathrm{HaV}$ suspension $(25 \mathrm{ml})$ was inoculated. Each experiment was conducted in triplicate. Samples were taken immediately after gentle mixing, and then at 30 min intervals over a period of $120 \mathrm{~min}_{\text {; }}$ they were then diluted 10-fold with SWM3 medium and centrifuged at $3000 \mathrm{rpm}(800 \times \mathrm{g})$, at $4^{\circ} \mathrm{C}$ for $3 \mathrm{~min}$ to remove algal cells with adsorbed viruses. An aliquot of the resulting supernatant was fixed with glutaraldehyde at a final concentration of $1 \%$. The unadsorbed virus particles were directly counted using epifluorescence microscopy following the protocol of Weinbauer \& Suttle (1997) with partial modifications. Briefly, DAPI solution - $15 \mu \mathrm{g} \mathrm{ml}^{-1}$ DAPI in Tris buffer $(10 \mathrm{mM}$ Tris$\mathrm{HCl}, 10 \mathrm{mM}$ EDTA-Na, $100 \mathrm{mM} \mathrm{NaCl}, 10 \mathrm{mM}$ 2-mercaptoethylamine hydrochloride, $\mathrm{pH} 7.4$; Hamada \& Fujita 1983) - was added to each fixed sample (final concentration of DAPI $=1 \mu \mathrm{g} \mathrm{ml}^{-1}$ ) and the samples were incubated in the dark for $30 \mathrm{~min}$. The stained

Table 1. Heterosigma akashiwo. Viral susceptibility (+: lysed, -: not lysed) of $4 \mathrm{H}$. akashiwo strains to HaV01 and HaV53

\begin{tabular}{|lcc|}
\hline Strain & HaV01 & HaV53 \\
\hline H93616 & + & + \\
H98518-4 & + & - \\
H94608 & - & + \\
H98527-6 & - & - \\
\hline
\end{tabular}

samples were collected on $0.02 \mu \mathrm{m} \quad \mathrm{Al}_{2} \mathrm{O}_{3}$ filters (Anodisk 25, Whatman). The damp filters were mounted on a glass slide with a drop of low-fluorescence immersion oil and covered with a cover slip and another drop of the immersion oil. A minimum of 20 to 100 particles positively stained with DAPI were counted in 20 fields using an Olympus BX50 microscope equipped with a wide UV filter set; thus, the direct count estimates of $\mathrm{HaV}$ were calculated. The most probable number (MPN) of unadsorbed viruses was also enumerated using the extinction dilution method (Suttle 1993, Tarutani et al. 2000). Briefly, the remaining supernatant was diluted with SWM3 in a series of 2- to 10-fold dilutions, and aliquots of each dilution were added to 8 wells in 96-well microtiter plates containing exponentially growing $H$. akashiwo H93616 cultures. The cultures in microtiter plates were incubated under the conditions given above and checked daily for 10 to $14 \mathrm{~d}$ for cell lysis. The dilution of culture wells in which cell lysis occurred was scored, and the MPN of infectious virus particles was determined using the BASIC program (Hurley \& Roscoe 1983). The adsorption coefficient $\left(C_{d i} \mathrm{ml} \mathrm{min}^{-1}\right)$ was determined as follows (Cottrell \& Suttle 1995):

$$
C_{d}=\frac{\alpha-\alpha_{C}}{N}
$$

where $\alpha\left(\mathrm{min}^{-1}\right)$ is the slope, $\alpha_{c}\left(\mathrm{~min}^{-1}\right)$ is the slope determined by linear regression for the natural logarithm of the percentage of free viruses in control culture against sampling time, and $N\left(\right.$ cells $\mathrm{ml}^{-1}$ ) is the host cell number.

\section{RESULTS AND DISCUSSION}

There was a pronounced difference in the number of $\mathrm{HaV}$ in the stock suspension enumerated by the 2 methods; direct count estimates by epifluorescence microscopy and MPNs by the extinction dilution method (MPN assay). The MPN of HaV01 was $1.2 \pm 0.2$ $\times 10^{6} \mathrm{ml}^{-1}(\mathrm{n}=5)$ and was $\sim 3 \%$ of the direct count estimate at $3.8 \pm 0.5 \times 10^{7} \mathrm{ml}^{-1}(\mathrm{n}=5)$. The HaV53 stock suspension had an MPN estimate of $0.96 \pm 0.15 \times 10^{6}$ $\mathrm{ml}^{-1}$ ( $\mathrm{n}=5$ ), which was $\sim 4 \%$ of the direct count estimate at $2.2 \pm 0.4 \times 10^{7} \mathrm{ml}^{-1}(\mathrm{n}=5)$. Similar differences have been reported for other algal viruses: MpV (Cottrell \& Suttle 1995), Phaeocystis pouchetii virus ( $\mathrm{PpV}_{\text {; }}$ Bratbak et al. 1998), and HcV (Y. Tomaru et al. unpubl. data). The direct count method detects all of the virus particles with dsDNA (stainable with DAPI) whether they are infectious or not, whereas the MPN assay detects only 'infectious' virus particles. This indicates that only a small fraction of the $\mathrm{HaV}$ particles in the lysed cultures were infectious. 


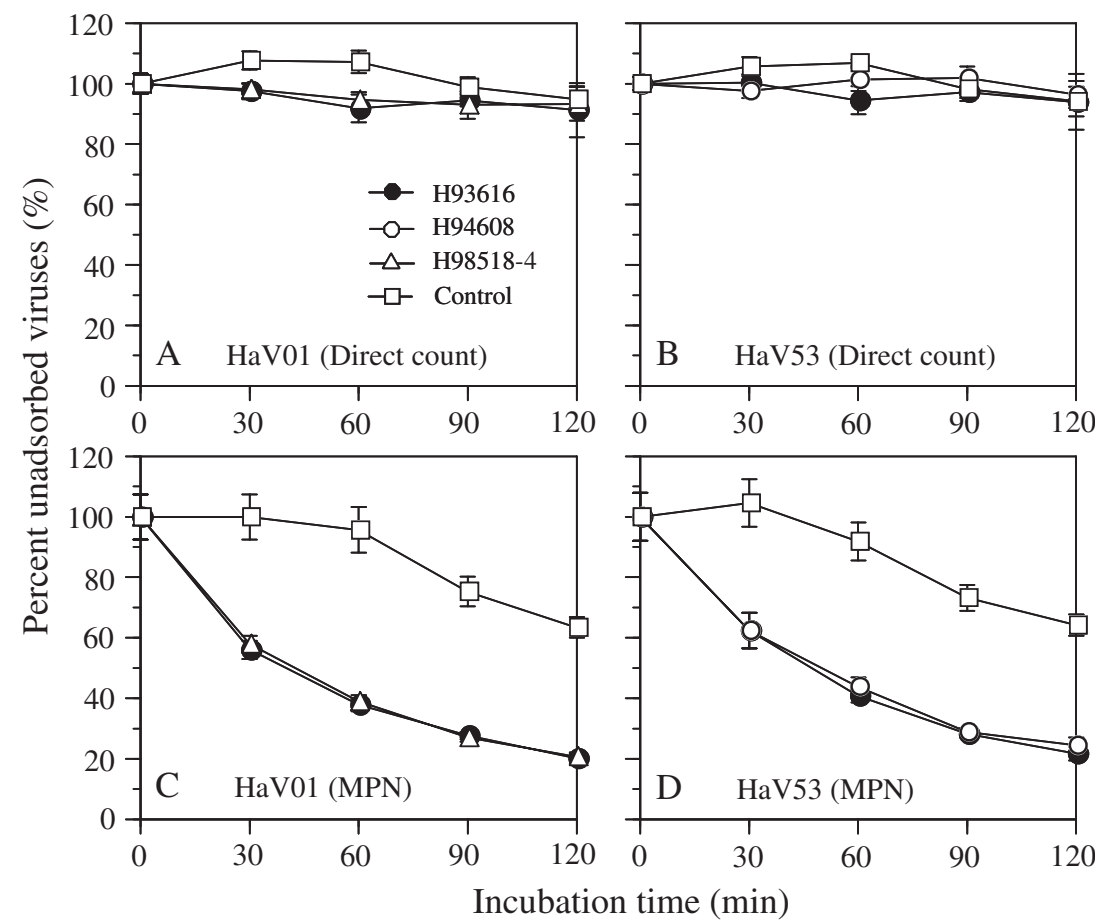

Fig. 1. Heterosigma akashiwo. Changes in the relative proportion of $(A, C)$ HaV01 and $(B, D)$ HaV53 particles that were unadsorbed to their suitable host strains as measured by $(\mathrm{A}, \mathrm{B})$ the direct count method or $(\mathrm{C}, \mathrm{D})$ the extinction dilution method. Vertical bars indicate standard deviation $(n=3)$. For the control experiments see 'Materials and methods'

When HaV01 was inoculated into a suitable host culture (H93616 or H98518-4; Table 1), the direct count estimates of free HaV01 particles were not significantly different from those of the control cultures (Fig. 1A). In contrast, the MPN of infectious virus particles showed a significant decrease during the experiments, and at 120 min post-inoculation the abundance was $\sim 20 \%$ of the initial value (Fig. 1C). Similar results were obtained with HaV53 and its suitable host strains (H93616 and H94608; Table 1), i.e. no significant decline in the direct count estimates (Fig. 1B) but a noticeable decline in the MPN (Fig. 1D). As mentioned above, MPN of infectious HaV particles made up only a small proportion ( 3 to $4 \%$ ) of the direct count estimates in these cultures. There may have been no remarkable decrease in the direct count estimates as the proportion of HaV particles adsorbed to Heterosigma akashiwo cells was too small to be reflected in the direct count estimates; indeed, the range of decrease in free virus numbers due to adsorption to host cells was less than the counting errors of direct count estimates (Fig. 1A,B). Based on these observations, we concluded that only the 'infectious' HaV particles were able to adsorb to their suitable host cells and cause infection.

One possible explanation for why only a small portion of $\mathrm{HaV}$ particles were infective is that a large pro- portion of virus particles had adsorbed to algal cell debris generated through the process of host cell degradation (Cottrell \& Suttle 1995). This would inactivate newly generated viruses and inhibit their adsorption to new host cells. Another possibility is that a significant proportion of the virus particles released into the environment were immature, i.e. most $\mathrm{HaV}$ particles lacked a mature surface structure, and thus were not able to adsorb to the virus receptor of Heterosigma akashiwo.

The adsorption coefficients of HaV01 and HaV53 to the sensitive Heterosigma akashiwo strains calculated from the changes in the MPN estimate had a range of 4.0 to $5.4 \times 10^{-8} \mathrm{ml} \mathrm{min}^{-1}$ (Table 2 ). These values are higher than those previously reported for other algal viruses, e.g. $\mathrm{MpV}$ $\left(1.4 \times 10^{-9} \mathrm{ml} \mathrm{min}^{-1}\right.$; Cottrell \& Suttle 1995) and cyanophage S-PM2 $\left(6.2\right.$ to $6.7 \times 10^{-9}$

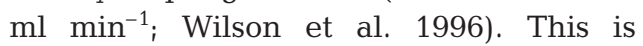
presumably due to the larger cell volume of $H$. akashiwo in comparison to the other host algal species.

The adsorption coefficient can be theoretically estimated using diffusive transport of the viruses to the host cells (Murray \& Jackson 1992). Assuming the diameters of $\mathrm{HaV}$ and Heterosigma akashiwo are 0.2 and $15 \mu \mathrm{m}$, respectively, and the swimming velocity of $H$. akashiwo is 20 to $160 \mu \mathrm{m} \mathrm{s}^{-1}$ (Smayda 1998), the theoretical adsorption coefficient for $H$. akashiwo and $\mathrm{HaV}$ was estimated to be 3.3 to $6.7 \times 10^{-8} \mathrm{ml} \mathrm{min}^{-1}$. This agrees well with the value measured in the present study $\left(4.0\right.$ to $5.4 \times 10^{-8}$ $\mathrm{ml} \mathrm{min}^{-1}$ ). These results suggest that the adsorption kinetics of infectious HaV particles is subject to the diffusive transport theory.

When HaV01 was inoculated into its resistant Heterosigma akashiwo strain cultures (H94608 and H98527-6; Table 1), the free virus particles (direct count estimates) did not show any significant decrease in abundance (Fig. 2A). The MPN of infectious virus

Table 2. Heterosigma akashiwo. Adsorption coefficient $\left(\times 10^{-8}\right.$

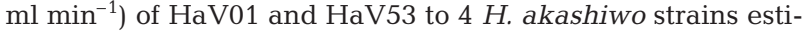
mated by the most probable number (MPN) assay. Values show average $\pm \mathrm{SD}(\mathrm{n}=3)$. - : no significant differences compared to the control culture

\begin{tabular}{|lcc|}
\hline Strains & HaV01 & HaV53 \\
\hline H93616 & $5.4 \pm 0.3$ & $5.4 \pm 0.7$ \\
H98518-4 & $4.8 \pm 0.2$ & - \\
H94608 & - & $4.0 \pm 0.2$ \\
H98527-6 & - & - \\
\hline
\end{tabular}




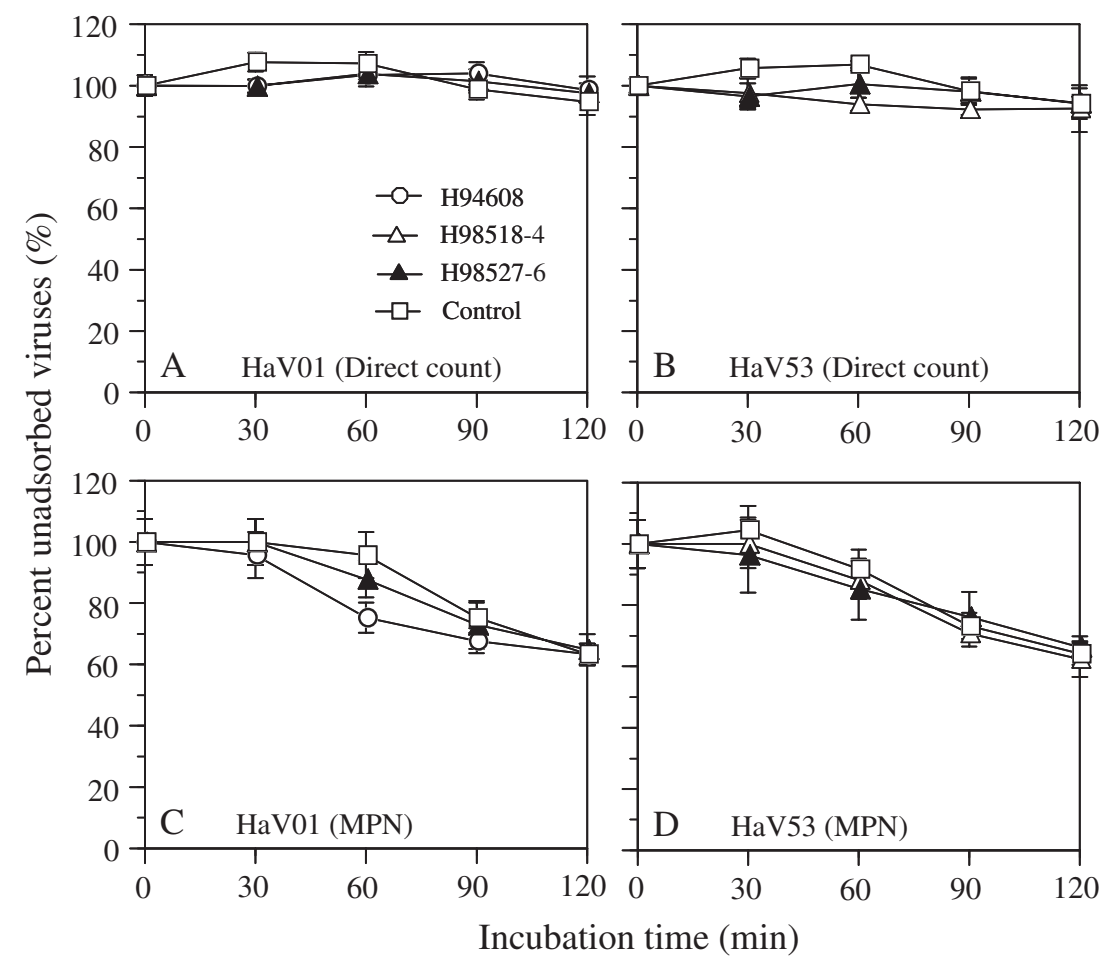

Fig. 2. Heterosigma akashiwo. Changes in the relative proportion of $(\mathrm{A}, \mathrm{C})$ HaV01 and $(\mathrm{B}, \mathrm{D}) \mathrm{HaV} 53$ particles that were unadsorbed to their unsuitable host strains measured by $(A, B)$ the direct count method or $(C, D)$ the extinction dilution method. Vertical bars indicate $\pm \mathrm{SD}(\mathrm{n}=3)$. For the control experiments see 'Materials and methods'

particles decreased slightly during the experiments but the change was not significantly different from the control culture (Fig. 2C); this may reflect the gradual loss of $\mathrm{HaV}$ infectivity through the incubation under the condition mentioned above (see 'Materials and methods') (Nagasaki \& Yamaguchi 1998). In addition, with HaV53 and its resistant host strains (H98518-4 and H98527-6; Table 1), the changes in the number of free viruses were not significantly different from those in the control cultures using either the direct count method or MPN assay (Fig. 2B,D). These results indicate that $\mathrm{HaV}$ adsorbed hardly at all to the resistant strains. Furthermore, viral adsorption may be the primary process in determining the sensitivity or resistance of $H$. akashiwo strains to viral infection, which would account for the strain-specific host range of $\mathrm{HaV}$.

\section{CONCLUSION}

The data presented here suggest that the strain-specific host specificity of $\mathrm{HaV}$ is determined during the viral adsorption process. Development of resistance to viral infection is often related to lysogeny, especially in the case of bacteriophages (e.g. Bisen et al. 1986), which is one of the predominant tactics for bacteriophages to be multiplied in accordance with their hosts' propagation (Wilson \& Mann 1997). However, lysogeny is unknown for viruses infecting eukaryotic marine algae except for Ectocarpus siliculosus virus-1 (EsV-1) infecting the brown alga E. siliculosus (Delaroque et al. 1999). The HaV-DNA polymerase gene fragment is highly conserved among $\mathrm{HaV}$ clones and was not detected in the genome of Heterosigma akashiwo strain H93616 using PCR experiments, even though it shows apparent resistance to a number of $\mathrm{HaV}$ strains (Nagasaki et al. 2005b, Tomaru et al. 2004b); this rules out the possibility of lysogeny as the cause of the virus resistance observed here. A more plausible explanation is that resistance develops at the level of the algal cell wall, as observed in bacteriophages infecting Streptomyces erythreus (Donadio et al. 1986). Some biochemical variation may exist on the cell surface among $H$. akashiwo ecotypes with distinct virus sensitivity spectra.

To understand the adsorption mechanism of $\mathrm{HaV}$, it is essential to identify and characterize the communication between the hosts' virus receptor and the viral surface protein. In the case of $\mathrm{CV}$, a viral-surface glycoprotein Vp260 with 13 internal tandem repeats of 61 to 65 amino acids is suggested to cause variations in nature of the viral surface (Que et al. 1994, Chuchird et al. 2002). A putative $\mathrm{HaV}$ gene encoding a protein with more than 20 internal tandem repeats of $\sim 74$ amino acids has been identified and is now under examination (Y. Shirai unpubl. data). This is of particular interest for determining whether these structures are involved in the host strain specificity of $\mathrm{HaV}$.

Acknowledgements. We are grateful to Dr. Y. Tomaru of the National Research Institute of Fisheries and Environment of Inland Sea, Fisheries Research Agency, for his technical assistance. This study was partly funded by the Fisheries Agency of Japan, the Ministry of Agriculture, Forestry and Fisheries of Japan, the Industrial Technology Research Grant Program in 2000-2004 from the New Energy and Industrial Technology Development Organization of Japan (NEDO) and the Japan Science and Technology Corporation.

\section{LITERATURE CITED}

Bisen PS, Audholia S, Bhatnagar AK, Bagchi SN (1986) Evidence for lysogeny and viral resistance in the cyanobacterium Phormidium uncinatum. Curr Microbiol 13:1-5

Bratbak G, Jacobsen A, Heldal M, Nagasaki K, Thingstad F (1998) Virus production in Phaeocystis pouchetii and its 
relation to host cell growth and nutrition. Aquat Microb Ecol 16:1-9

Chen LCM, Edelstein T, McLachlan J (1969) Bonnemaisonia hamifera Hariot in nature and in culture. J Phycol 5: 211-220

Chuchird N, Nishida K, Kawasaki T, Fujie M, Usami S, Yamada $\mathrm{T}$ (2002) A variable region on the chlorovirus CVK2 genome contains five copies of the gene for Vp260, a viral-surface glycoprotein. Virology 295:289-298

Cottrell MT, Suttle CA (1991) Widespread occurrence and clonal variation in viruses which cause lysis of a cosmopolitan, eukaryotic marine phytoplankter, Micromonas pusilla. Mar Ecol Prog Ser 78:1-9

Cottrell MT, Suttle CA (1995) Dynamics of a lytic virus infecting the photosynthetic marine picoflagellate Micromonas pusilla. Limnol Oceanogr 40:730-739

Delaroque N, Maier I, Knippers R, Müller DG (1999) Persistent virus integration into the genome of its algal host, Ectocarpus siliculosus (Phaeophyceae). J Gen Virol 80: $1367-1370$

Donadio S, Paladino R, Costanzi I, Sparapani P, Schreil W, Iaccarino M (1986) Characterization of bacteriophages infecting Streptomyces erythreus and properties of phage-resistant mutants. J Bacteriol 166:1055-1060

Hamada S, Fujita S (1983) DAPI staining improved for quantitative cytofluorometry. Histochemistry 79:219-226

Hurley MA, Roscoe ME (1983) Automated statistical analysis of microbial enumeration by dilution series. J Appl Bacteriol 55:159-164

Imai I, Itakura S, Matsuyama Y, Yamaguchi M (1996) Selenium requirement for growth of a novel red tide flagellate Chattonella verruculosa (Raphidophyceae) in culture. Fish Sci 62:834-835

Itoh K, Imai I (1987) Raphidophyceae. In: Japan Fisheries Resource Conservation Association (ed) A guide for studies of red tide organisms. Shuwa, Tokyo, p 122-130

Lawrence JE, Chan AM, Suttle CA (2001) A novel virus (HaNIV) causes lysis of the toxic bloom-forming alga Heterosigma akashiwo (Raphidophyceae). J Phycol 37: $216-222$

Murray AG, Jackson GA (1992) Viral dynamics: a model of the effects of size, shape, motion and abundance of singlecelled planktonic organisms and other particles. Mar Ecol Prog Ser 89:103-116

Nagasaki K, Yamaguchi M (1997) Isolation of a virus infectious to the harmful bloom causing microalga Heterosigma akashiwo (Raphidophyceae). Aquat Microb Ecol 13: 135-140

Nagasaki K, Yamaguchi M (1998a) Intra-species host specificity of $\mathrm{HaV}$ (Heterosigma akashiwo virus) clones. Aquat Microb Ecol 14:109-112

Nagasaki K, Yamaguchi M (1998b) Effect of temperature on the algicidal activity and stability of $\mathrm{HaV}$ (Heterosigma akashiwo virus). Aquat Microb Ecol 15:211-216

Nagasaki K, Tarutani K, Yamaguchi M (1999a) Growth characteristics of Heterosigma akashiwo virus and its possible use as a microbiological agent for red tide control. Appl Environ Microbiol 65:898-902

Nagasaki K, Tarutani K, Yamaguchi M (1999b) Cluster analysis on algicidal activity of $\mathrm{HaV}$ clones and virus sensitivity of Heterosigma akashiwo (Raphidophyceae). J Plankton Res 21:2219-2226

Nagasaki K, Tomaru Y, Tarutani K, Katanozaka N, Yamanaka S, Tanabe H, Yamaguchi M (2003) Growth characteristics and intra-species host specificity of a large virus infecting the dinoflagellate Heterocapsa circularisquama. Appl
Environ Microbiol 69:2580-2586

Nagasaki K, Tomaru Y, Katanozaka N, Shirai Y, Nishida K, Itakura S, Yamaguchi M (2004) Isolation and characterization of a novel single-stranded RNA virus infecting the bloom-forming diatom Rhizosolenia setigera. Appl Environ Microbiol 70:704-711

Nagasaki K, Shirai Y, Takao Y, Mizumoto H, Nishida K, Tomaru Y (2005a) Comparison of genome sequences of single-stranded RNA viruses infecting the bivalve-killing dinoflagellate Heterocapsa circularisquama. Appl Environ Microbiol 71:8888-8894

Nagasaki K, Shirai Y, Tomaru Y, Nishida K, Pietrokovski S (2005b) Algal viruses with distinct intraspecies host specificities include identical intein elements. Appl Environ Microbiol 71:3599-3607

Onimatsu H, Sugimoto I, Fujie M, Usami S, Yamada T (2004) $\mathrm{Vp130}$, a chloroviral surface protein that interacts with the host Chlorella cell wall. Virology 319:71-80

Que Q, Li Y, Wang IN, Lane LC, Chaney WG, Van Etten J (1994) Protein glycosylation and myristylation in Chlorella virus PBCV-1 and its antigenic variants. Virology 203: $320-327$

Reisser W, Burbank DE, Meints SM, Meints RH, Becker B, Van Etten JL (1988) A comparison of viruses infecting two different Chlorella-like green algae. Virology 167: 143-149

Sahlsten E (1998) Seasonal abundance in Skagerrak-Kattegat coastal waters and host specificity of viruses infecting the marine photosynthetic flagellate Micromonas pusilla. Aquat Microb Ecol 16:103-108

Smayda TJ (1998) Ecophysiology and bloom dynamics of Heterosigma akashiwo (Raphidophyceae). In: Anderson DM, Cembella AD, Hallegraeff GM (eds) Physiological ecology of harmful algal blooms. Springer-Verlag, Berlin, p 113-131

Suttle CA (1993) Enumeration and isolation of viruses. In: Kemp PF, Sherr B, Sherr E, Cole JJ (eds) Handbook of methods in aquatic microbial ecology. Lewis Publishers, Boca Raton, FL, p 121-137

Tarutani K, Nagasaki K, Yamaguchi M (2000) Viral impact on total abundance and clonal composition of the harmful bloom-forming phytoplankton Heterosigma akashiwo. Appl Environ Microbiol 66:4916-4920

Throndsen J (1996) Note on the taxonomy of Heterosigma akashiwo (Raphidophyceae). Phycologia 35:367

Tomaru Y, Katanozaka N, Nishida K, Shirai Y, Tarutani K, Yamaguchi M, Nagasaki K (2004a) Isolation and characterization of two distinct types of HcRNAV, a singlestranded RNA virus infecting the bivalve-killing microalga Heterocapsa circularisquama. Aquat Microb Ecol 34:207-218

Tomaru Y, Tarutani K, Yamaguchi M, Nagasaki K (2004b) Quantitative and qualitative impacts of viral infection on a Heterosigma akashiwo (Raphidophyceae) bloom in Hiroshima Bay, Japan. Aquat Microb Ecol 34:227-238

Weinbauer MG, Suttle CA (1997) Comparison of epifluorescence and transmission electron microscopy for counting viruses in natural marine waters. Aquat Microb Ecol 13: 225-232

Wilson WH, Mann NH (1997) Lysogenic and lytic viral production in marine microbial communities. Aquat Microb Ecol 13:95-100

Wilson WH, Carr NG, Mann NH (1996) The effect of phosphate status on the kinetics of cyanophage infection in the oceanic cyanobacterium Synechococcus sp. WH7803. J Phycol 32:506-516

Submitted: February 22, 2005; Accepted: January 23, 2006

Proofs received from author(s): March 22, 2006 